\title{
Die verbondsverhouding as basis vir klag en lof in Psalm 42 en 43
}

\author{
J.L. Helberg \\ Dept. Ou \& Nuwe Testament \\ Potchefstroomse Universiteit vir $\mathrm{CHO}$ \\ POTCHEFSTROOM
}

\begin{abstract}
Psaims 42 and 43 form a unity and can be regarded as one song, containing elements of lament as well as of praise. Thus, however contradictory, lament and praise are integrated in a unity as both elemenis have a common ground, namely a specific relation between God and his people. As is customary in most other songs of lament it is not stated clearly what the relation is. Most commentators of this song do not offer more than a statement of the relation in general tems. This fact may relate to the recent trend to date the covenont in the exilic or post-exilic period, a trend which has come to the fore especially since the study of Perlitt (1969) about the covenant in the Old Testament. In this article an attempt is made to indicate that there is a covenantal relation underlying Psalm 42 and 43, a covenantal relation which is not institutionally or formally dominated and which is not only group-orientated but also strongly individual-orientated. Attention will, inter alia, be given to the concept expressed in words like: nemember (zkr),

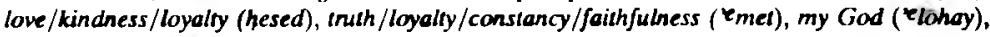
vindicate me (Jop(eni) and plead my cause (ribe rbI).
\end{abstract}

\section{INLEIDING}

Psalm 42 en 43 vorm 'n eenheid en kan as een lied gereken word: dié lied bevat diepe klag en sterk lofbetuiging. Ook word dit duidelik dat hoe teenstellend klag en lof ook al is, die klag en lof hier saam 'n eenheid vorm omdat hulle dieselfde grond het, naamlik ' $n$ bepaalde verhouding van God met sy volk. Wat hierdie verhouding is, word, soos gewoonlik in klaagpsalms, nie uitdruklik gesê nie. Die meeste nuwere verklaarders van Psalm 42 en 43 gaan dan ook nie verder as om in algemene terme van hierdie verhouding te praat nie. Hierdie feit mag saamhang met die huidige tendens om die verbond eers in die tyd van die ballingskap of na die ballingskap te dateer, 'n tendens wat veral sedert die studie van Perlitt (1969) na vore getree het. In hierdie artikel word gepoog om aan te dui dat daar 'n verbondsverhouding ten grondslag van Psalm 42 en 43 lê, ' $n$ verbondsverhouding wat nie dominant institusioneel of formeel is nie, en ook nie alleen groepsgerig is nie, maar ook 'n sterk individuele gerigtheid het.

Die volgende punte sal bespreek word: die aard en eenheid van hierdie lied; die bevraagtekening van die digter se geloof in die lewende God deur hom beantwoord 
met "gedenk" ( $z k r)$ (eerste strofe); die deurbreek van die hesed van Jahwe in verbinding met die digter se "gedenk" (tweede strofe); God se lig en sy trou as die oplossing (derde strofe); samevatting en gevolgtrekking.

\section{DIE AARD EN EENHEID VAN PSALM 42 EN 43}

Hierdie twee Psalms word algemeen as een indiwiduele klaaglied beskou (vgl. byvoorbeeld Kraus, 1972:318), met die gevolg dat hier nie op dié aspek ingegaan hoef te word nie. Hier kan volstaan word deur daarna te verwys dat Psalm 43 nie 'n opskrif het nie, dat daar drie duidelike strofes is met dieselfde afsluitende refrein $(42: 6 ; 42: 12 ; 43: 5)$ en dat daar 'n duidelike voortgang in gedagte is. In die eerste strofe stel die digter sy heimwee na God, in die tweede strofe verklaar hy sy terneergedruktheid en in die derde strofe rig hy pleitredes tot God (vgl. veral Raabe, 1990:46-50). Gerstenberger $(1991: 179,182)$ beskou die lied as deel van die aanbidding in die sinagoge in die Persiese tyd, 'n lied in ooreenstemming met die algemene gevoel van onsekerheid en hoop van die Jode wat gely het onder die magtige, politeistiese en minagtende gemeenskap. Die gebed is bedoel om elke lid van die gemeente te versterk in die aangesig van pynlike vernedering.

Die digter se hele bestaan in al sy verhoudinge is in gedrang: sy verhouding tot God, sy naaste en homself. Die beheersende gedagte van sy lied is sy heimwee na God, en dit word reeds heel aan die begin uitgespreek. Die digter verwys graag na homself in terme van "my nepeš", 'n woord wat'n wye betekenis het en wat weergegee kan word met woorde soos 'my siel' (intensief vir 'ek'), 'my wese', 'my persoon', 'my lewe'; 'ek' (vgl. Westermann, 1976:77-88). Die woord nepeś word hier sewe keer gebruik en God een en twintig keer, in eweredige verspreiding. Die naam Jahwe kom een keer voor en wel in die sentrum van die lied (42:9; vgl. Raabe, 1990:46). Die naam van God wat in die Ou Testament sterk geassosieer word met Israel se redding uit Egipte en hulle besondere verhouding met God, het dus 'n sentrale plek in die lied en dit word hier voorts verbind met sy liefde en trou (hašdô). Die woord hesed druk'n spontane, onvoorwaardelike oopwees vir iemand uit, 'n oorgawe aan iemand, liefde, verbondenheid, vriendskap en goedheid. Daar bestaan nooit 'n regsaanspraak op hesed nie, maar 'n mens kan om God se hesed bid en daarop wag. Die Psalmdigters neem God se vroeèr ervare hesed as grond vir hulle hoop en kan nie aanvaar dat God se hesed kan versand nie. Hulle reken daarmee dat God se hesed ook konsekwent is; daarom gebruik hulle dikwels die gekombineerde uitdrukking hesed we' berger, 1982:66,67,185,187). God se hesed impliseer dus tegelykertyd sy liefde en sy trou en het in hierdie lied 'n verbondenheidskonnotasie, of, anders gestel, 'n verbondskonnotasie. Die digter se heimwee is 'n heimwee na die "lewende God", die God wat oor alles heerskappy voer en wat reddend optree. Juis hierdie hoedanigheid van God gee aanleiding tot die klag en lof, want die digter ervaar die teendeel. God tree nie op nie, en as Hy optree, is dit op die teenoorgestelde manier as wat verwag sou kon word. 
Die digter voel dat sy basiese verhoudinge daardeur ernstig aangetas is.

Die lied getuig van 'n besonder innige verhouding tussen die digter en God. Behalwe deur aangrypend te begin om sy heimwee na God uit te druk, praat hy dikwels van "U/u" - "ek/my" (as parallelle, 42:2,7,8,10,12; 43:2,3,4,5). Dikwels word ook gepraat van "my God" (42:7,12; 43:4,6), "my Rots" (42:10), "my Skuiling" (43:2), "jou God" (deur die vyande gesê, 42:4,11). Taylor (1955:220) vat dié beskrywing raak saam: "From beginning to end the impression of the immediacy of the psalmist's communion with God is comparable only to what we meet in such prayers as Jer 14:19-22; 15:1518; 20:7-18; Exod 33:13-16." Dit gaan hier tegelykertyd om meer as net 'n blote indiwiduele verhouding, soos blyk uit die digter se heimwee na die "lewende God", die God wat in beheer van alle dinge en alle gebeurtenisse is. Die verhouding het ' $n$ geskiedenis wat in herinnering geroep word (42:5) en wat saam met die ander aanbidders in die huis van God afspeel (42:5; 43:4). Die hoofsaak is dat God geloof word (43:4). Die bedoeling van Psalm 42 en 43 is dan ook meer as om net aan indiwiduele smart uiting te gee: die digter wil mense wat in vertwyfeling is, aanspoor om te bly hoop. Teen alle skyn van die werklikheid in dat God nie optree ten behoewe van dié wat Hom getrou dien nie, moet sy lesers van hierdie psalms vashou aan die gemeenskap met God. Die selfaansporing tot hoop wat in die refrein vervat is, is besonder geskik om hierdie idee van aansporing te ondersteun. Die grond vir hierdie hoop is die verbondsverhouding met Jahwe. Hierdie verhouding word egter gesien as 'n verhouding wat geen grond bied vir 'n outomatiese aanspraak op redding of op God se besondere teenwoordigheid nie. Verbondsverhouding is 'n verhouding wat gebed vereis, dit wil sê dit is 'n verhouding wat die elemente van 'n versoek en pleitrede asook van volharding in vertroue en hoop bevat.

Die bestaan van 'n verbondsverhouding tussen God en Israel in die vroeë tyd van Israel se bestaan word vandag van verskillende kante bevraagteken. Kreuzer (1983:359) oordeel egter dat die tema van verbondsreg in kern geldig is en beswaarlik ten volle uit Israel se vroeë tyd uitgeskakel kan word. Nicholson $(1986: 215,216)$ kom tot die volgende gevolgtrekking:

\footnotetext{
The concept of a covenant between Yahweh and lsrael is, in terms of 'cash value', the concept that religion is based, not on a natural or ontological ecquivalence between the divine realm and the human, but on choice: (God's choicc of his people and their 'choicc' of him, that is, their free decision to be obedient and faithful to him. Thus understood, 'covenant' is the central expression of the distinctive faith of Israel as 'the people of Yahweh', the children of God by adoption and free decision rather than by nature or necessity. This has been obscured somewhat by too narrow a concentration on questions of terminology, and lost sight of altogether in the (fruitless) quest to find ancient parallels in the sphere of social institutions.
}

Psalm 42 en 43 in geheel en die hantering van die begrip liefde/trou in besonder bevestig hierdie laaste stelling van Nicholson.

Hierdie klaaglied is een waarin daar as 't ware 'n klag teen God gerig word. Hierdie 
klag (complaint, Anklage) word deur sommige navorsers (soos Westermann, 1977:159,164; Broyles, 1989:40,221 en Fuchs, 1982:307) gesien as 'n aparte kategorie, maar deur andere, soos Gerstenberger (1980:60-63;134-147) as deel van 'n klaaglied. Vir die doel van hierdie artikel hoef nie op hierdie verskil van mening ingegaan te word nie. Dit staan in elk geval vas dat daar in alle indiwiduele klaag- of dankliedere in 'n mindere of meerdere mate vertroue uitgedruk word (vgl. Keel, 1969:221). Soos gewoonlik die geval is by die klaagliedere wat 'n klag teen God bevat, is hier geen skuldbelydenis nie. Die afwesigheid van so 'n belydenis moet nie gesien word as 'n reaksie teen die sogenaamde Deuteronomistiese teologie wat onheil aan sonde toeskryf nie. Die eintlike swaartepunt van die problematiek in Psalm 42 en 43 lê anders: dit gaan om God se trou aan iemand wat Hom van harte soek te midde van mense wat geen erns maak met so 'n verhouding nie, 'n verhouding wat aan bepaalde maatstawwe voldoen en wat in 'n regsgeding $(r i b, 43: 1)$ getoets kan word. Dit is wel nie God wat in die regsgeding getoets word nie, maar die digter. Tog pleit die digter op 'n sekere reg kragtens die bepaalde verhouding met God ("Laat tog reg aan my geskied" (šoptênî); "behartig my saak" (rîbâ ribî). Daarmee pleit hy indirek dat God Hom aan 'n bepaalde maatstaf moet hou, hoewel hy dit dwarsdeur die lied vermy om God te bind aan 'n maatstaf wat buite Homself is.

Die feit dat die digter heimwee het na die huis van God, pleit vir 'n ontstaanstyd toe die tempel nog bestaan het (Ridderbos, 1958:11); ander dateer Psalm 42 en 43 in die na-ballingskapse periode (Gerstenberger, 1991:182), al meen hulle dat daar ook ouer elemente aanwesig is (bv. Kreuzer, 1983:273). Daar moet ook rekening gehou word met die feit dat hierdie lied sekere ooreenkomste vertoon met Klaagliedere 3 (vgl. die sterk nadruk op hoop in 'n oënskynlik verlore situasie, 3:1-18; die sterk indiwiduele aanslag en die nadruk op "gedenk" ( $z k r), 3: 19$ e.v.). Verder is daar ooreenkomste met Klaagliedere 5:22 (vgl. die vashou aan God se verbondstrou sonder om in verbondsoutomatisme te verval; vgl. Helberg, 1990:382-384). Met hierdie gegewens in gedagte hoef die lied in elk geval nie 'n na-ballingskapse ontstaan te hê nie.

\section{DIE BEVRAAGTEKENING VAN DIE DIGTER SE GELOOF IN DIE LEWENDE GOD BEANTWOORD MET "GEDENK" (ZKR)}

Die grondliggendheid van die digter se probleem is duidelik in die beginwoorde oor sy heimwee na God (42:2), waarin hy homself vergelyk met 'n wildsbok wat smag na die basiese lewensmiddel, water. Die hele aarde sit as 't ware met 'n grondliggende bestaansprobleem. Die digter gebruik die uitdrukking "my nepeš smag", wat beteken 'ek smag', maar wat tog volheid uitdruk en wil sê 'my (hele) persoon smag'. Ook die uitdrukking "my aangesig" (pănay 42:6) benadruk die hele persoon (Vorländer, 1975:281). Die digter verlang nie na 'n onbekende God nie, maar na die enige ware God, wat sy Naam, sy wese en sy wil deur sy profete bekend gemaak het (Lamparter, 1961:220; Reventlow, 1986:174). Die digter verlang na "die lewende God" (42:3): 
hierdie uitdrukking beklemtoon God se almag en sy heerskappy oor sy volk en ten behoewe van sy volk, met ander woorde sy reddende optrede vir hulle (Kreuzer, 1983:275; vergelyk bl. 271, 272 oor die gebrek aan grond om die tekslesing te verander na: "die God van my lewe" soos in 42:9). Dié uitdrukking is ook teenstellend tot die lewelose afgode wat deur die heidene vereer is en wat nie daadwerklik by die gebeurtenisse betrokke is nie (Ridderbos, 1958:13). Die digter verlang nie net na God as die bron van die lewe nie, maar na die lewende God self. God is vir hom die lewe. Kreuzer (1983:274) stel dit vertaald soos volg:

\begin{abstract}
Lewe beteken om voor Jahwe, by Hom, tc mag lewe en nie uilgesluit te wees van sy nabyheid en van die gemeenskap van dié wal aan Hom behoort nie. Die onderliggende lewensbegrip gaan uit van die gemeenskap en word gekonkretiseer in dic enkcling, waarby die beslissing gednen word aan die hand van kriteria van die regslewe. Die God in wie se Naam hierdie beslissing geneem word, is Jahwe, die lewende God.
\end{abstract}

Die nabyheid van Jahwe, die lewende God, word op 'n besondere manier op Sion in sy heiligdom beleef; by Hom is lewe, redding, regverdiging en vreugde (Kreuzer, 1983:273). Daarom wil die digter "ingaan" (42:3) - 'n tegniese term vir 'n besoek aan die heiligdom - en hy wil die "gesig van God te sien" ('er'eh) - so lui sommige Hebreeuse manuskripte asook die Siriese vertaling, maar die Massorete het die lesing verander na "voor God verskyn" ('èra'eh; vgl. Ridderbos, 1958:13,14). Hierdie verskil in lesing maak nie ' $n$ wesenlike verskil aan die betekenis nie. Om die gesig van God te sien, of voor Hom te verskyn, is meer as om net die tempel te besoek, en beteken om in 'n innige gemeenskap met God te kan tree (Reindl, 1970:156; Van der Ploeg, 1973:264).

Die digter se bestaan en bestaansorde is egter basies aangetas en omgekeer. In plaas van water te kan drink, moet hy van sy trane lewe, dag en nag (42:4). Die vyande vra die hele dag spottend vir hom: "Waar is jou God?". Hulle beweer dat God nie die verhouding waarop die digter aanspraak maak, bevestig nie. Die werklikheid van die digter se bestaan bevestig nie 'n verhouding van versorging en beskerming nie, maar eerder die teendeel. In die tweede strofe kom duidelik na vore dat dit nie net die vyande is wat hom hierdie smart aandoen nie, maar dat God eintlik daarvoor verantwoordelik is.

Die sleutel of pad wat die digter gebruik om uit sy probleem te probeer kom, is om te "gedenk" ( $z k r)$ (42:5), om die gebeurtenisse wat vroeër aan die verhouding tussen hom en God uitdrukking gegee het, in herinnering te roep. In die Ou Testament het "gedenk" ( $z k r$ ) betrekking op meer as bloot op denke: in die herinnering word die verlede vasgegryp omrede sy betekenis vir die hede en met die oog op die huidige optrede (Scottroff, 1964:339). Die digter se "gedenk" het egter eerder die teenoorgestelde effek. Hy wil die verhouding van die verlede vasgryp in lofsegging aan God, saam met die aanbidders in die huis van God. Wat gebeur het en gewees het, wil hy as maatstaf neem om die huidige probleemsituasie op te los. Die huidige situasie is egter juis die omgekeerde van die verlede. Daarom gaan die digter oor in klag (42:6), 'n 
klag wat ook die hoofrefrein van die lied vorm $(42: 6 ; 42: 12 ; 43: 5)$.

Hierdie klag bevat egter 'n selfvermaning oor die vertwyfeling, en 'n selfopwekking tot hoop op God. Die rede wat die digter daarvoor aangee, is dat hy God "weer" sal "loof". Die refrein bevat klag en lof tegelyk. "Weer" ('ôd) verwoord nie maar 'n magtelose troos in die sin van 'toemaar, alles sal regkom' nie; ook impliseer dit nie 'n sikliese denke waarvolgens alles herhaal word, en waarom ook die tyd van voorspoed dus weer sal aanbreek nie. Die uitdrukking hou ook nie in dat God van die digter se lof afhanklik is en hom sal red sodat hy God daarvoor kan loof nie. Die digter se lof is meer as net dank vir wat God gee en gaan om wat God is: die lewende God; dit is na God self wat die digter verlang. Hierdie feit kom nog duideliker na vore in 43:3,4 (vgl. die bespreking in 5). Teen die werklikheid van God se oënskynlike afwesigheid of gebrek aan optrede in, gryp die digter aan God vas in hoop. (Oor die res van die refrein se woorde sal in punt 5 gehandel word.)

\section{DIE DEURBREEK VAN DIE $H S D$ VAN JAHWE IN VERBINDING MET DIE DIGTER SE "GEDENK" (ZKR)}

Die bevraagtekening van die digter se besondere verhouding met God is meer as net honende vyandstaal. Die digter beleef die situasie self as die harde, onloënbare werklikheid. Daarom kan hy (sy nepes) nie tot rus kom nie en begin hy in die tweede strofe (42:7) om hierdie onrus en vertwyfeling aan God te stel. Weer is "gedenk" sy middel of pad om 'n oplossing te soek. Hier is 'n voortgang op 42:5 waar die "gedenk" gerig was op die gebeurtenisse van die verlede: saam met die gemeente in lofsange. Nou word die verhouding bepaaldelik op God betrek: "Ek dink aan U".

Die digter is verstoke van die geleentheid om God deur die bestaande middele op te soek. Die rede hiervoor is heel konkreet, geografies-histories: hy is in 'n landstreek ver weg van Jerusalem waar God se heiligdom is. Daar is dus vir hom nie slegs ' $n$ geestelike verhindering om naby God te wees nie. Ook is die verhindering nie aan iets mitologies toe te skryf nie. Israel se bure het byvoorbeeld geglo aan 'n stryd tussen die goeie gode en die magte van die chaos waardeur die aardse lewe bepaal word. Die digter van Psalm 42 plaas nie alleen sy situasie binne die geografiese raamwerk van 'n bepaalde plek nie, maar ook sy vergelyking met die wildsbok $(42: 2)$ plaas sy lied binne die raamwerk van hierdie konkrete aardse lewe.

Die probleem van die digter draai om meer as net dat hy sonder die geleenthede is om God te kan opsoek, of dat hy hierdie geleenthede ontsê is. Die situasie en die gebeurtenisse is anders as wat dit behoort te wees; hulle is heeltemal onderstebo gekeer. Bowendien ervaar die digter daarin 'n doelbewuste optrede van God: "U het golf na golf oor my laat slaan" - letterlik: "Al u golwe en u branders het oor my gegaan" (42:8). Hierdie gedagte is 'n voortgang op 42:4. In sy dors na God kry die digter nie 
slegs sy trane om te drink nie, maar God stuur op 'n bitter ironiese manier watermassas wat hom oorstroom en laat verdrink. Met hierdie beeldgebruik sluit die digter waarskynlik aan by die konkrete watervalle in die omgewing waar hy hom bevind, die Hermonberg (vgl. Ridderbos, 1958:16; Goulder, 1982:28 meen dit is die omgewing van Dan). Tog is hier waarskynlik ook 'n sinspeling op die buurnasies se geloof in die mitologiese oervloed (tehom) (vgl. Van Uchelen, 1977:14) en die mitologiese chaos wat die aardse bestaan bedreig. Soos uit die bogenoemde ruimtelike verwysings (die wildsbok en die plek) blyk, is die magte hier egter 'gehistoriseer' en het die mitologiese aspek 'n blote beeld geword (vgl. Kreuzer, 1983:273; vgl. ook die mitologiese seemonster Rahab en Leviatan, Ps. 74:14; 89:11; 104:26). Die nie-mitologiese aard van die situasie blyk ook uit die uitdrukkings wat nie net van golwe en branders praat nie, maar van "u" golwe en "u" branders. Daarmee word God se optrede beklemtoon. God gee die digter oor aan die aanvegtinge wat sy bestaan en die bestaan van alle dinge raak. So kom die sinvolheid van God se heerskappy oor alles onder ' $n$ vraagteken te staan.

Die digter se diepste probleem is dus nie mitologies van aard nie; die onbegryplike en onverteerbare vir hom is dat God so optree, God wat in 'n verbondsverhouding met hom staan. God is sy probleem. God is die oorsaak van sy klag. Maar juis daarom kan hy van klag oorgaan na gebed en lof (vgl. ook die refrein). Juis in hierdie absolute dieptepunt, hierdie punt van ondergang, breek die digter se hoop deur (42:9) en gee hy uiting aan sy vertroue in die liefde en trou (hesed) van Jahwe. Hesed-is wel iets waarop nie aanspraak gemaak kan word nie en wat nie onder 'n verpligting staan nie. Tog is hesed hier iets wat van 'n verhouding geld en nie net van 'n oombliksituasie nie; dit gaan om 'n optrede wat verwag sou kon word. Die uitdrukking hasdô behoort hier tot die verbondsfeer. Sakenfeld (1978:230,231) stel dit soos volg:

\footnotetext{
Hesed is God's faithfulness given expression as protection, deliverance, or forgiveness. The relational vocabulary which is used (c.g. trust, hope, know, servant) suggests the importance of the covenant imagery in which the suppliant expects and hopes that his trust is not misplaced and that he will receive freely given protection and support ... God's hesed is the providential exercise of his power on behalf of the needy people with whom he has established a special relationship.
}

Die hesed waarom dit hier gaan, is spesifiek die hesed van "Jahwe". Hierdie naam kom in Psalm 42 en 43 net hier voor, teenoor die een en twintig keer van die naam "God" ('elohîm). Die naam Jahwe staan hier in die middel van die lied (vgl. ook Raabe, 1990:46,47). Dit gaan om Jahwe wat bekend is vir sy besondere verhouding met sy volk en die besondere (verbonds)geskiedenis wat Hy met hulle het. Hy het hulle uit Egipte gered, met hulle 'n verbondsverhouding daargestel en dit van sy kant getrou onderhou. Dit is 'n verhouding wat "gedenk" ( $z k r$ ) kan word. In die dieptepunt van sy leed "gedenk" die digter daarom vir God (42:7; Nuwe Afrikaanse Vertaling: "roep ek na U"). Die betoning van die hesed van Jahwe in $42: 9$ hang ten nouste saam met hierdie "gedenk". Childs (1962:61) sê in verband met $z k r(42: 5,7)$ : die digter dink aan die verlede - hy beleef dit saam met die aanbiddende gemeente in Jerusalem. In sy twyfel 
strek die digter hom uit tot God in herinnering. Dan beleef hy inderdaad die hesed van Jahwe. Childs $(1964: 64,65)$ sê verder in verband met $z k r$ dat daar iets nuuts is in die betekenis daarvan. In die intense worsteling om 'n verband met die tradisie te lê, beleef Israel opnuut die verlede deur middel van sy geheue. Israel se aandag is nie langer toegespits op bepaalde historiese gebeurtenisse nie, maar op die Goddelike werklikheid wat Israel se geskiedenis afgestempel (imprinted) het ... Die woord $z k r$ het 'n geweldige verinnerliking van betekenis ondergaan. Om te gedenk/onthou/herinner is om te gryp na, om te peins oor, om inderdaad tot God te bid. Childs gaan wel te ver wanneer hy aan $z k r$ 'n aktualiseringsbetekenis toeskryf, asof God se verlossingsoptrede van die verlede in die kultus in Jerusalem geaktualiseer is. Die lied lewer geen spoor daarvan nie (vgl. ook Scottroff, 1964:339).

Die hesed van Jahwe is inderdaad sy hesed (hasdô, 42:9). Hy alleen beskik daaroor en niemand kan daarop aanspraak maak asof hy daarop reg het nie. Geen verhouding en geen verbond kan maak dat God outomaties of meganies tot een of ander optrede geforseer word nie. Die verhouding tussen Hom en sy volk bly dié van Skepper tot skepsele. Hy bly in sy optrede die vrymagtige God. Die weg tot Hom bly die weg van gebed, van versoek of pleiting, nie van eis nie. Hierdie feit word verder beklemtoon deur die werkwoord wat hier saam met hesed gebruik word, naamlik: "gebied" (swh). In sommige tekste word $s w h$ vir God se skeppingsbevel gebruik of vir sy bevel om iets besonders in die natuur te laat gebeur (Jes. 5:6; 45:12; Ps. 33:9; 78:23; 148:5; Job 37:12; vgl. Liedke, 1976:534). Ook hier word die woord in so 'n betekenis gebruik. God sal met sy skeppingsmagtige bevel die digter se ondergangsituasie verander en uitkoms bewerk. Soos Hy op 'n wonderdadige manier sy volk as 't ware uit die dood in Egipte gered het en met hulle 'n verbondsverhouding aangegaan het, so sal Hy nou met skeppersmag sy verbondsliefde teenoor die digter laat geld. Al die aandag is hier op God se mag, inisiatief en trou toegespits: Hy gebied en dit is sy liefde en sy lied wat by die digter is. Dit is God se optrede wat die dryfveer is om die digter ' $n$ lied te laat sing. Hierdie lied is ' $n$ lied tot die "God van my lewe", die God wat aan die digter die lewe gee en sy lewe in stand hou (42:9). Lewe is nie maar om eenmaal die lewe te ontvang en dan vanself te lewe nie. Lewe moet as 't ware voortdurend deur God gegee word en deur die gelowige voortdurend ontvang word.

Hierdie lied vertoon 'n sterk ooreenkoms met Klaagliedere 3. Ook daar is dit by die dieptepunt van bestaan en van twyfel dat die digter se hoop opvlam tot vaste vertroue (Klaagl. 3:18,55). Ook daar speel "gedenk" (zkr) 'n belangrike rol (Klaagl. 3:19); so ook die liefde van Jahwe (hasdê JHWH; Klaagl. 3:22), die selfaansporing tot hoop (Klaagl. 3:24), 'n regsaak (rîb Klaagl. 3:36) en verskaffing van reg deur Jahwe (špt; Klaagl. 3:58,59). Klaagliedere 3 word oor die algemeen nie lank na die val van Jerusalem gedateer nie, 'n feit wat dus ook eerder pleit vir 'n vroeëre datering van Psalm 42 en 43 as laat-ballingskaps of na-ballingskaps (behalwe as Kaiser [1981:302] se datering in die vierde eeu voor Christus korrek is - 'n vraag wat egter nie hier uitgemaak kan word nie). 
Ondanks die digter se uiting van vertroue in die liefde en trou van Jahwe is sy worsteling nog daar weens God se ironiese optrede. Die digter uiter 'n klag, 'n negatiewe belydenis: "Ek wil vir God sê: My Rots, waarom vergeet U my?" (42:10). God maak hom 'n weerlose prooi vir die vyand en laat hom verteer word deur smart en verleentheid. Die rede hiervoor is die vyand se minagting en hulle formulering van die probleem dat daar geen daadwerklike optrede van God is wat hierdie verhouding bevestig nie (42:11). Tog, in hierdie dieptepunt van betwyfeling van sy verhouding met God deur die vyand, vlam die digter se hoop weer op. Dit word uitgedruk in die refrein waarin hy homself vermaan en bemoedig (42:12).

\section{GOD SE LIG EN SY TROU AS DIE OPLOSSING}

In die derde strofe "gedenk" ( $k$ kr) die digter nie meer nie. Die "gedenk" wat telkens die klag oor die ironiese verskil tussen die verlede en die smartlike hede opgeroep het, gee nou daartoe aanleiding dat die digter hom direk tot God rig en 'n bepaalde optrede vir die hede vra. Hy pleit dat daar reg aan hom moet geskied (soptëni) en dat God vir hom sy regsaak moet hehartig (werihâ ribî; 43:1; vgl. Ps. 35; Van Uchelen, 1977:17). Hier is dit duidelik dat die verhouding tussen die digter en God meer as net 'n oombliksverhouding of 'n ad hoc-verhouding is, want meer as net 'n spontane, indiwiduele tussenpersoonlike handeling is ter sprake. 'n Erkende patroon van optrede, ' $n$ erkende basis word veronderstel, en wel een waarin daar 'n sekere juridiese maatstaf ter sprake is. Hierdie Skrifgedeelte bevestig Kreuzer (1983:274) se verbandlegging tussen die nabyheid van God, die gemeenskap van die gelowiges en die persoonlike beslissing aan die hand van kriteria uit die regslewe. So is dit in verband met God se hesed (42:9). Die hesed is die vrug van God se lewewekkende inisiatief en optrede en dit berus by sy vrymag. Tog is daar 'n maatstaf vir sy optrede en skep dit 'n sfeer van reg (špt en rîh). Die digter vra so 'n optrede teen 'n gôy lô(') hạasid. Hierdie versoek moet teen die agtergrond van die voorafgaande (42:1-12), en veral die uitspraak oor Jahwe se hesed in 42:9 gesien word. Dit gaan hier om mense wat nie binne die sfeer van God se hesed val, dink en optree nie. Hulle dink nie in terme van die hesed van Jahwe wat 'n historiese pad van redding met sy volk geloop het nie en daarom betoon hulle ook geen medemenslikheid nie. Dit is nie duidelik of hier ' $n$ heidense volk bedoel word of mense uit Israel self nie, en of die betekenis algemener is en alle mense insluit wat nie ware gelowiges is nie (vgl. Ridderbos, 1958:18; Deissler, 1964:176,177; Gerstenberger, 1991:182).

Die digter vra om offisieel, formeel in die gelyk gestel te word. Hy het behoefte aan meer as sy subjektiewe geloof en vasgrype aan God. Tog laat hy God vir geen oomblik as absolute sentrum en grond van optrede verdring word deur 'n 'objektiewe' maatstaf of grond nie. Die digter begin deur God sterk voorop te stel: "Net $U$ (we'attâ) is my skuiling, my God" (43:2). Weer word die voornaamwoorde "U"-"my" gebruik om uit- 
drukking te gee aan 'n noue verhouding. Weer het die digter vrymoedigheid tot klag oor die ongerymdheid van sy situasie wat die omgekeerde is van wat dit behoort te wees. Weer gaan dit om 'n doelbewuste optrede van God: God verwerp hom (znh). Hier is 'n intensivering in vergelyking met $42: 10,11$. God "vergeet" $(\breve{k} k h)$ hom nie net nie, maar "verstoot" ( $z h h)$ hom; die vyande spot hom nie net nie, maar tree misdadig teenoor hom op.

Die sleutel wat die digter vir die oplossing van sy saak sien, is dat God moet optree. Hy moet sy lig en waarheid "stuur" (shl ; 43:3). "Stuur" sien hier op God se inisiërende en skeppende optrede, soos die "gebied" van sy hesed in 42:9 en die "stuur" van sy Gees (rûah) in Psalm 104:30 ("U stuur u (rûah uit en hulle word geskep"). Die "gedenk" van die digter (en so ook die gemeente se "gedenk" in die kultus) is 'n middel om te vra vir God se verlossende optrede soos in die verlede, maar daar is geen sprake van ' $n$ outomatiese werking nie. Alles berus by God se inisiatief en optrede: hy moet "stuur". Die digter sal en moet wag en bly bid, soos uitgedruk deur die refrein van die lied.

Ook die digter se versoek om God se lig en waarheid is 'n versoek om bemiddeling en wys dat dit hier om meer gaan as net 'n subjektiewe verhouding. Hier is bemiddeling deur God se lig en sy waarheid. Weer eens word die noue verhouding tussen die digter en God egter beklemtoon. In ooreenstemming met die sterk persoonlike of verhoudingskarakter van die lied vra die digter nie bloot om "lig" en "waarheid" as selfstandige entiteite nie, maar om " $u$ lig" en " $u$ waarheid". Dit word gestel langs "my lei" en "my bring" en word opgevolg met " $u$ heilige berg, $u$ woning". Verder spreek die digter sy verlange uit na die altaar van God (43:4), maar die toespitsing is geheel en al op die verhouding met God self: "die God oor wie ek wil jubel en juig, dat ek U kan loof met die lier, o God, my God!" Hier bereik die lied sy einde (behalwe dat die refrein weer volg) en sy klimaks. Dit gaan vir die digter ten diepste om God te loof, en wel in hierdie innige, persoonlike verhouding, soos uitgedruk in die woorde "my God" (vgl. Eissfeldt, 1945/48:12,14 vir die warme en innige Godsgemeenskap in hierdie term; vgl. verder Schmidt, 1971:162; Ringgren, 1973:299,300 oor die verband met klag, vertroue, hoop en dank). Met hierdie laaste woorde sluit ook die refrein af.

In hierdie psalm is nie sprake van "lig en waarheid" as rasionele begrippe wat 'n rasionele verklaring van die digter se probleem gee nie. Uit die feit dat 'emet hier nie saam met hesed voorkom nie maar saam met "lig", lei Gerstenberger (1991:181) af dat hier moontlik 'n ontwikkeling in die rigting van die wysheidsliteratuur is en dit hier dus 'n verwysing na die tora kan wees, want lig is die simbool van God se kommunikasie en van die menslike persepsie van waarheid en krag (Ps. 39:10; 119:105; Job 12:25; Spr. 6:23). Teenoor hierdie benadering van Gerstenberger staan egter die gegewe dat die spreker van die heiligdom verstoke is (Ps. 42:5) en dat hy die Woord hier nie sien as die subjek wat hom na die heiligdom of gemeente moet lei nie, maar as die objek waaraan hy daar in die samekoms van die gemeente deel wil hê. Die digter wil uit sy geografiese afstand (42:7,8), gepaard met ander hindernisse, gelei en gebring word na 
die tempel om God daar saam met die gemeente te aanbid (vgl. Preuss, 1973:539 vir $b \hat{o}\left(\right.$ (') $^{\prime}$ in die sin van aanbid). Lig is die simbool van God se beskermende en reddende teenwoordigheid (Job 29:3; Ps. 18:29; 27:1; 36:10; 97:11; Jes. 9:1; 58:8; vgl. Aalen, 1973:175; Saebo, 1971:88-90). Waarheid ('emet) kom dikwels saam met hesed voor en dui die bestendigheid van God se liefde aan (Kellenberger, 1982:185), sy trou (Wildberger, 1971:202; Jepsen, 1973:339), veral sy trou aan sy verbondsbeloftes (Ps. 25:10; $40: 11,12 ; 57: 4 ; 61: 8 ; 85: 11 ; 88: 12 ; 89: 15,25,29 ; 92: 3$; ens.). Die "stuur" van "u lig en u waarheid" hier in Psalm 43:3 hou verband met "Jahwe" se "gebied" van sy hesed in 42:9 en druk in wese dieselfde gedagte uit.

Die konkrete situasie van die digter kan wel vergelyk word met verdrinking en met ' $n$ situasie waar chaosmagte skynbaar heers (42:8). Verder bevat "u lig" 'n sinspeling op God se bevryding van sy volk uit Egipte toe Hy hulle snags met 'n lig gelei en hulle na hulle land toe gebring het. Die tabernakel, sy heilige woning, het toe 'n belangrike rol gespeel. Hier word die tabernakel met sy tempel geïdentifiseer (Eks. 15). Die digter beroep hom dus op God se reddende teenwoordigheid en kragdadige trou soos in die geskiedenis van sy volk vergestalt en in die kultus bely en herdenk - die verbondsverhouding.

Die lied sluit af met die refrein (43:5). In die refrein word die situasie van verlatenheid oorwin deur hoop, en wel hoop op God self. Die digter se hoop is tegelykertyd 'n hoop ter wille van God: om Hom weer te loof. Die situasie moet weer wees soos die digter se verlede saam met die volk met wie God'n besondere geskiedenis het, God wat die Verlosser is: dit alles is saamgetrek in die afsluitingswoord "my God" ('elohay). Hiermee word uitdrukking gegee aan 'n verbondsverhouding. Dit is juis kragtens hierdie verhouding wat die digter sy situasie van verlatenheid bekla maar tegelykertyd daar bokant uitstyg in lof aan God.

Die verbondsverhouding is wel persoonlik, maar is nie 'n private saak nie. Daarom is ook die klag en die lof (vgl. Mayer, 1981:464) nie bloot'n private saak nie maar is dit ook bedoel vir bemoediging van die lede van die gemeenskap. Waarskynlik het die groep deur middel van die refrein aan hulle gemoedstemming uiting gegee.

Die verbondsbenadering kan die elemente akkommodeer wat in die volgende benaderings oor die wending van klag na lof aangesny word: religieus-psigologies - ' $n$ innerlike wending in die bidder (Heiler); ritueel-tegnies - 'n aankondiging van 'n heilsorakel deur 'n kultusbeampte (Begrich); 'n heilsvergegenwärtigende funksie van die klag wat met lof gepaard gaan (Beyerlin; vgl. oor hierdie drie benaderings Reventlow, 1986:172-173). 


\section{SAMEVATTING EN GEVOLGTREKKING}

Die lied in Psalm 42 en 43 adem 'n verbondsatmosfeer. Dit blyk uit terme soos: gedenk ( $z k r)$, liefde en trou (hesed), trou ('emet), my God ('elohay), laat tog reg aan my geskied (šoptęnî), behartig tog my saak (ribâ rîbî). Die lied vertolk 'n besonder intiem indiwidueel-persoonlike verhouding tussen die digter en God, en verteenwoordig tegelyk ' $n$ binding aan die kultus en die gemeente waar gemeenskaplike lofbetuiging aan God gedoen word. Tegelykertyd vertolk die lied 'n verhouding wat rus in 'n historiese en plegtige verbintenis, met sekere juridiese implikasies vir Israel. Die digter kan om regsverskaffing in 'n regsaak teen die vyand pleit. Daar is egter geen sprake van so 'n regsaak teen God nie, die digter kan wel by Hom teen Hom kla, maar ten diepste kan hy slegs pleit en hy kan hoop. Die pleitrede en hoop kan realiseer op grond van God se liefde en trou (hasdô, 42:9; 'emittekâ, 43:3) wat gepaard gaan met sy skeppende, lewewekkende magswoord of bevel ( $s w h, 42: 9 ; \check{s} l h, 43: 3)$.

Die tema van die lied is die digter se heimwee na God, die lewende God, die God wat oor alles heerskappy uitoefen. God is tegelykertyd die "God van my lewe", die God wat die lewe gee en onderhou en selfs uit 'n ondergangsituasie uitkoms kan bewerk. Hy is verder "my God", met wie die digter 'n innige en onverbreeklike verhouding het. Die digter sien die oorsaak van sy situasie van verlatenheid en verstotenheid nie as iets bloot van die oomblik nie, ook nie as die vrug van mitologiese magte nie. Die situasie kan wel in beelde uit daardie sfeer geteken word, maar die oorsaak is iets konkreets, iets histories. Die situasie van verlatenheid spruit voort uit die gegewe van vyande wat hom leed verskaf en veral God se optrede. Hierdie optrede is in dié sin teen-histories dat Hy teen die aard van sy verbond in, teenoor die digter optree. Hy staan in 'n verbondsverhouding met die digter. Juis hierdie verhouding is die grond vir die digter se klag omdat sy situasie in werklikheid die omgekeerde is van wat dit behoort te wees. Tegelykertyd is die verbondsverhouding die grond vir die digter se lof aan God wat saam met sy klag gestel word.

As verbondsverhouding is die digter se verhouding met God 'n verhouding met 'n geskiedenis; daarom wend die digter gedenk aan as middel in sy soeke. Sy gedenk is veral op God self gerig en die vrug hiervan is die sekerheid dat Jahwe sy liefde en trou, sy verbondsliefde (hasdô) sal gebied. Jahwe, wat sy volk wonderbaarlik uit Egipte bevry het, sal nou soos met 'n skeppingsbevel sy verlossende verbondsliefde aan die digter bewys en hom uit die ondergangsituasie bevry. Jahwe behou hierin egter die volle inisiatief. Die gedenk val in die kader van versoek en gebed en kan nie iets bewerkstellig of aktualiseer nie. Die digter sal, en moet op God wag in hoop, soos die refrein ook benadruk. In die derde strofe van die lied is daar dan ook geen "gedenk" nie, maar 'n direkte versoek tot God dat Hy sy lig en sy waarheid, sy reddende teenwoordigheid en sy verbondstrou sal stuur: dit moet die digter saam met die gemeente in die heiligdom bring waar hy die gemeenskap met God kan soek en Hom kan loof. Die lied trek saam in hierdie lof van die digter aan God in 'n verhouding wat 
uitgedruk word in die term my God en wat uitdrukking gee aan 'n verbondsverhouding.

Nicholson (1986:216) se eerste sinsnede oor verbond in die Ou Testament is te kategories en sluit blykbaar 'n vroeë verbondsluiting uit, maar 'n studie van Psalm 42 en $\mathbf{4 3}$ bevestig wel die res van sy konklusie:

So far from being a social institution, the covenant represents the refusal of prophets and their disciples to encapsulate Yahweh's relationship with his people in institutions, and to insist that it depends on a moral commitment on both sides which needs to be continually reaffirmed in faithful conduct, not taken for granted (as were institutions such as the monarchy in the ancient world) as though it were part of the order of nature.

Die verbondsverhouding in Psalm 42 en 43 gee 'n pleitgrond vir die digter, maar die verbond is nie iets wat verselfstandig is of 'n grond buite God self nie. Hier is ' $n$ binding tussen God en die digter wat nóg grond bied vir aanvaarding van ' $n$ outomatiese redding of 'n minimum van indiwiduele verantwoordelikheid en aanspreeklikheid, nóg grond bied vir wanhoop. Daar is egter wel grond vir hoop. Die kultus en die gemeente is die sfeer waarin die digter as lid van die verbondsgemeenskap wil aanbid en sy aanbidding trek ten diepste saam in 'n persoonlike verhouding van lof aan God, saamgevat in die kernwoord van die lied se klimaks: "my God".

\section{BIBIJOGRAFIE}

AALEN, S. 1973. 'wr (In Bolterweck, G.J. \& Ringgren, H. reds. Theologisches Worterbuch zum Alten Testament. I. Stuttgart: Kohlhammer. p. 160-182.)

BROYLES, C.C. 1989. The Conflict of Faith and Experience in the Psalms: A Form-Critical and Theological Study. Sheffield : JSOT Press. (Journal for the Study of the Old Testament Supplement Series.)

CHILDS, B.S. 1962. Memory and Tradition in lsrael. London : SCM. (Studies in Biblical Theology.)

DEISSLER, A. 1964. Dic Psalmen. Düsseldorf : Patmos Verlag.

EISSFELDT, O. 1945/48. "Mein Goll" im Altcn Testament. Zeitschnft für die Altestamenliche Wissenschaft, 61:3-16.

FUCHS, O. 1982. Die Klage als Gebet: eine theologische Besinnung am Beispiel des Psalms 22. München : Köscl.

GERSTENBERGER, E.S. 1980. Der bittende Mensch: Bittritual und Klagelied des Einzelnen im Alten Testament. Neukirchen : Neukirchener Verlag.

GERSTENBERGER, E.S. 1991. Psaims. I. Grand Rapids : Eerdmans. (The Forms of the Old Testament Literature.)

GOULDER, M.D. 1982. The Psalms of the Sons of Korah. Shefficid : JSOT Press. (Journal for the Study of the Old Testament Supplement Series.)

JEPSEN, A. 1973. 'mn. (In Botterweck, G.J. \& Ringgren, H. reds. Theologisches Wörterbuch zum Alten Testament. I. Stuttgart : Kohlhammer. p. 313-348.)

HELBERG, J.L. 1990. Land in the Book of Lamentations. Zeitschrift für die Alusestamentliche Wissenschaft, 102(3): 372-385.

KAISER, O. 1981. Klagelieder. (In Ringgren, H. \& Kaiser, O. Das Hohe Lied/ Klagelieder/ Das Buch Esther. Gôttingen : Vandenhocck \& Ruprechı. Das Alte Testament Deutsch. p. 291-386.)

KEEL, O. 1969. Feinde und Gottesleugner. Stultgart : Katholisches Bibelwerk. (Stuttgarter Biblischc Monographien.) 
KELLENBERGER, E. 1982. häsäd wa'ámăt als Ausdruck einer Glaubenserfahrung: Gottes Offen-Werden und Bleiben als Voraussetzung des Lebens. Zủrich : Theologischer Verlag Zürich. (Abhandlungen zur Theologic des Alten und Neuen Testaments.)

KRAUS, HJ. 1972. Psalmen. 1. Neukirchen-Vluyn : Neukirchener Verlag. (Biblischer Kommentar Altes Testament.)

KREUZER, S. 1983. Der lebendige (jott: Bedeulung, Herkunft und Entwicklung einer alttestamentlichen Gottesbezcignung. Stuttgart : Kohlhammer. (Beiträge zur Wissenschaft vom Alten und Neuen Testament.)

LAMPARTER, H. 1961. Das Buch der Psalmen. II. Stuttgart : Calwer Verlag. (Die Botschaft des Alten Testaments.)

LIEDKE, G. 1976. \$wh pi. Befehlen. (In Jenni, E. \& Westermann, C. reds. Theologisches Handworterbuch zum Alten Testament. II. Munchen : Kaiser Verlag. p. 530-536.)

MAYER, G. 1981. jdh (In Bolterweck, G.J. \& Ringgren, H. reds. Theologisches Worterbuch zum Alten Testament. III. Stuttgart : Kohlhammer. p. $460-474$.)

NICHOLSON, E.W. 1986. God and His People; Covenant and Theology in the Old Testament. Oxford : Clarendon Press.

PERLITT, L. 1969. Bundestheologic im Alten Testament. Neukirchen-Vluyn : Neukirchener Verlag. (Wissenschaftliche Monographien zum Alten und Neuen Testament.)

PREUSS, H.D. 1973. bw'. (In Bottcrweck, G.J. \& Ringgren, H. reds. Theologisches Wörterbuch zum Alten Testament. I. Stuttgart : Kohlhammer. p. 536-568.)

RAABE, P.R. 1990. Psalm Structures: A Study of Psalms with Refrains. Shefficld : JSOT Press. (Journal for the Study of the Old Testament Supplement Series.)

REINDL, J. 1970. Das Angesicht Gottes in Sprachgebrauch des Alten Testaments. Leipzig : St. BennoVerlag GMBH.

REVENTLOW, H.G. 1986. Gebet im Alten Testament. Stuttgart : Kohlhammer.

RIDDERBOS, J. 1958. De Psalmen. II. Kampen : Kok. (Commentaar op het Oude Testament.)

RINGGREN, H. 1973. 'elöhim. (In Botterweck, (;.J. \& Ringgren, H. reds. Theologisches Worterbuch zum Alten Testament. I. Stuttgart : Kohlhammer. p. 285-305.)

SAEBO, M. 1971. 'ōr Licht. (In Jenni, E. \& Westermann, C. reds. Theologisches Handwörlerbuch zum Alten Testament. 1. München : Kaiser Verlag. p. 84- 0 .)

SAKENFELD, Katharine D. 1978. The Meaning of hesed in the Hebrew Bible: A Ncw Inquiry. Missoula, Montana : Scholars Press. (Harvard Scmitic Muscum. Harvard Semitic Monographs.)

SCOTTROFF, W. 1964. 'Gedenken' im Alten Orient und im Alten Testament: die Wurzel zakar im semitischen Sprachkreis. Neukirchen-Vluyn i Neukirchener Verlag. (Wissenschaftliche Monographien zum Alten und Neuen Testament.)

SCHMIDT, W.H. 1971. 'elohim Gotl (In Jenni, E. \& Westermann, C. reds. Theologisches Handwörterbuch zum Alten Testament. I. München : Kaiscr Verlag. p. 153-167.)

TAYLOR, W.R. 1955. Psalms 1-71. (In Buttrick, G.A. red. The Interpreter's Bible. IV. New York : Abingdon Press. p. 3-378.)

VAN DER PLOEG, J. 1973. Psalmen. I. Roermond: J.J. Romen \& Zonen. (De Boeken van het Oude Testament.)

VAN UCHELEN, NA. 1977. Psalmen. It. Nijkerk : Callenbach. (Prediking van het Oude Testament.)

VORLÄNDER, H.V. 1975. Mein Gott: die Vorstellungen vom persönlichen Gott im Alten Orient und im Alten Testament. Neukirchen-Vluyn : Neukirchener Verlag. (Alter Orient und Altes Testament.)

WESTERMANN, C. 1976. naefaeš Secle. (In Jenni, E. \& Westermann, C. reds. Theologisches Handwörterbuch zum Alten Testament. II. München : Kaiscr Verlag. p. 71-96.)

WESTERMANN, C. 1977. Lob und Klage in den Psalmen. Gölingen : Vandenhoeck \& Ruprecht.

WILDBERGER, H. 1971. 'mn fest, sicher. (In Jenni, E. \& Westermann, C. reds. Theologisches Handworterbuch zum Alten Testament. I. München : Kaiser Verlag. p. 177-209.) 